\title{
Assessment of Sprague Dawley rats as biomodel in two antigenotoxicity assays
}

\author{
Arencibia- Arrebola D.F ${ }^{1 *}$, Rosario- Fernández L.A², Suárez-Fernández Y.E ${ }^{3}$, Vidal-Novoa $A^{4}$ \\ 1. Research Vicepresident (Finlay Institute), 17 avenue between 198 and 200 street. Playa Municipality. \\ Havana. Cuba. 2. Institute of Pharmacy and Food Science (IFAL, UH), 222 street between 25 and 27 \\ avenue. Lisa Municipality. Havana. Cuba. 3. Medicine Veterinary Faculty (UNAH), Highway to Tapaste. San \\ J osé Municipality. Mayabeque. Cuba. 4. Faculty of Biology, Havana University (U.H), 25 avenue between H \\ and J street. Plaza de la Revolución Municipality. Havana. Cuba. \\ * Corresponding author email: darencibia@finlay.edu.cu
}

Received: 05-05-2011, Accepted: 17-05-2011, Published Online: 05-09-2011

doi: $10.5455 /$ vetworld.2011.455-460

\begin{abstract}
The discovery of new drugs with antigenotoxic effect constitutes in our days a prioritized line of research. In this work was evaluated the response of Sprague Dawley rats (both sexes) against cyclophosphamide and bleomycin by means of alkaline comet assay of peripheral blood leukocytes and micronuclei in bone marrow cells assay as antigenotoxicy biomodel. Higher induction of the strand breaks (SB) and alkali-labile sites formation on DNA damage were obtained with the use of the cyclophosphamide and bleomycin, both in the design of 48 and $24 \mathrm{hr}$ administration before the euthanasia. In the mironucleis assay was obtained high results of induction the micronucleus formation in bone marrow cells with cyclophosphamide was administered 48 and $24 \mathrm{hr}$ before euthanasia in both sexes. These results are useful in studies of drugs evaluation that they have not been explored in to the in vivo antigenotoxicity environment.
\end{abstract}

Key words: Sprague Dawley, rats, biomodel, antigenotoxicity assays, micronucleus assay, comet assay.

\section{Introduction}

The discovery of new drugs with antigenotoxic effect constitutes in our days a prioritized line of research. At the same time many researchers develop and validate sensitive biomodels to the damages caused by the classic mutagens.

The strand breaks (SB) or alkali-labile sites formations on DNA are parameters broadly used for the genotoxicity detection and it has been demonstrated their associations with degenerative illnesses, cancer and oxidative stress (1). In 1988, Singh and collaborators developed the alkaline variant of the electrophoresis of individual cells (comet assay), providing for the first time data that demonstrate damage on DNA at individual cell level(2).

The micronuclei assay is easily to reproduce and its offer clear information on the cellular proliferation in bone marrow. These systems allow registering in vivo the capacity of the chemical substances to induce chromosomics ruptures to interfere with the chromosomes metaphases migration during the mitosis of the somatic cells (3).

The classic mutagens more used on in vivo genotoxicity studies are the cyclophosphamide (CF) and bleomycin (BL), administered by intraperitoneal route (4-6).

The first is an alquilant agent that forms monoadducts and crossed connections between chains as consequence of the appearance of ruptures for reparative mechanisms effects; the second induce liability and rupture of the structure of the DNA, to interchange with the oxygen and the iron, producing free radicals (5).

Both drugs are used with great effectiveness as antineoplastic. The CF belongs to the cloroethylamines group; considered a bifunctional alquilant agent, doesn't possess specificity for phase some of the cellular cycle. The BL is considered inside the group of the antibiotic tumorals (6).

At the present time the antigenotoxicity biomodels has little relevance due to the repetitive absence in the treatment outlines and to the mutagen selection. This bears to that the results of the induction of the damage on DNA and the reparative effects of the product that it is evaluated are questionable. For that the most of the substances with antigenotoxic character until the moment have been solely evaluated on in vitro assays. 
In this work was evaluated the response of Sprague Dawley rats (both sexes) against cyclophosphamide (CF) and bleomycin (BL) by means of alkaline comet assay of peripheral blood leukocytes and micronuclei in bone marrow cells assay as antigenotoxicy biomodel.

\section{Materials and methods}

Animals and environmental conditions: Rats Sprague Dawley young adults of both sexes was used (6-8 weeks) whose corporal weight oscillated among 180-210 $\mathrm{g}$ at the end of the quarantine, they where remained under controlled conditions: temperature $\left(25 \pm 1{ }^{\circ} \mathrm{C}\right)$, relative humidity $(60 \pm 10 \%)$ and cycles of light - darkness of $12 \mathrm{hr}$. The access to the water and the food (CENPALAB), it was ad libitum. These characteristics were common for all the experimental groups evaluated in both assays.

Experimental groups: In the experimental groups the substance were administered in the tomorrow's schedule and the concentrations were adjusted weekly in function of the corporal weight increase. The animals were randomly distributed 10 rats/group/sex. Five experimental groups were formed per sex. The first was administered with $\mathrm{NaCl} 0,9 \%$ by intraperitoneal (i.p) route (negative control group), at dose of $2 \mathrm{ml} / \mathrm{kg}$ in two occasions with intervals of 24 hr among both administrations.

The second and third groups were administered with CF at dose of $50 \mathrm{mg} / \mathrm{kg}$ by i.p route. The second group was administered in two occasions 48 and $24 \mathrm{hr}$ before the euthanasia and the third groups was only administered $24 \mathrm{hr}$ before the euthanasia, in both groups the $\mathrm{CF}$ was dissolved in $\mathrm{NaCl}$ to $0,9 \%$ at 10 $\mathrm{ml} / \mathrm{kg}$ (7). The fourth and fifth groups were administered with BL at dose of $40 \mathrm{mg} / \mathrm{kg}$ by i.p route. The fourth group was administered in two occasions 48 and $24 \mathrm{hr}$ before the euthanasia and the fifth group was only administered $24 \mathrm{hr}$ before the euthanasia, in both groups the $\mathrm{BL}$ was dissolved in $\mathrm{NaCl}$ to $0,9 \%$ at $10 \mathrm{ml} / \mathrm{kg}(8)$.

Assessments of the comet assay of peripheral blood leukocytes and the micronucleis assay in bone marrow cells: In both assay the evaluated cellular product was $24 \mathrm{hr}$ after the second administration of the evaluated substances for the first, second and fourth group. The evaluated cellular product was $24 \mathrm{hr}$ after the only administration for the third and fifth group.

The comet assay of peripheral blood leukocytes (alkaline electrophoresis of individual cells) was performed according to the standardized protocols and adjusted by Arencibia et al., 2010 (8). 15-20 $\mu \mathrm{L}$ of samples were suspended in $140 \mu \mathrm{L}$ of low melting point agarose to $0,5 \%$; then previously prepared sheets were added with agarose. They dove in lysis solution to $\mathrm{pH} 10$ for $1,5 \mathrm{hr}$ to $4^{\circ} \mathrm{C}$ and subjected to 20 min of denaturalization in electrophoresis regulatory solution, $\mathrm{pH}>13$. The electrophoresis was performed to $300 \mathrm{~mA}$ and $1 \mathrm{~V} / \mathrm{cm}$ during 18 to $20 \mathrm{~min}(1,2)$. The sheets were washed with solution neutralization regulatory using the Tris $0,4 \mathrm{M}$ to $\mathrm{pH} 7,5$ and clarified with distilled water and later they were tinted with silver nitrate to $0,05 \%(1,2)$. The nucleoids were evaluated using a microscope of light transmission, Olympus BH-2, for three independent observers, to establish an average among readings $(2,8)$. The visual analysis includes the quantification of 100 comets per animal in the gel center (2). The comets were classified chord to the category or degree of corresponding to DNA damage between 0 and 4 category. The magnitude of the DNA damage was expressed in arbitrary units (UA) $(2,8)$ starting from possible values in an interval of $0-400(1,2)$.

The micronucleis assay in bone marrow cells were performed according to the standardized protocols and adjusted by Arencibia et al., 2009 (9). It was extracted one femur per animal and the medullary cavity was washed kindly by flow with $3 \mathrm{~mL}$ of fetal bovine serum. The bone marrow cells obtained was centrifuged at $200 \mathrm{~g}$ for $10 \mathrm{~min}$; after eliminating the liquid it was performed an expansion of the cellular button in coverslips (9). After mounted the sheets (minimum: 2/animal) $24 \mathrm{hr}$ stayed to ambient temperature for its drying, and to fix in absolute methanol during $5 \mathrm{~min}$. They were tinted in Giemsa to $5 \%$ during $12-15 \mathrm{~min}(9)$. The analysis was performed for three independent observers, using a microscope Olympus BH-2 (100X with immersion lens). The presence of polychromatic erythrocytes (PE) and normochromatic erythrocytes (NE) in 2000 cells/animal were counted. Also, the frequency of PE with micronucleus (MN-EP) was calculated in 2000 PE/animal. Later on the cytotoxicity index was calculated (PE/NE) of the total population of erythrocytes and were counted the number of $\mathrm{PE}$ with $1 \mathrm{MN}, 2 \mathrm{MN}$ and $2 \mathrm{MN}$ per treatments group (9).

The method of euthanasia selected was the cervical dislocation with previous ether atmosphere. The continue variables were analyzed by ANOVA test $(p<0.05)$ and the categorical variables by Chi Squared $(\mathrm{p}<0.01)$. All the analyses were performed using the Statsoft for Windows. StatSoft, Inc. (2003). STATISTICA(data analysis software system), 6 version. 
Assessment of Sprague Dawley rats as biomodel in two antigenotoxicity assays

Table-1. Comet assay in Sprague Dawley rats of both sexes on the induction of DNA damage of peripheral blood leukocytes with Cyclophosphamide and Bleomycin.

\begin{tabular}{|c|c|c|c|c|c|c|c|}
\hline $\begin{array}{l}\text { Groups } \\
(\mathrm{mg} / \mathrm{Kg})\end{array}$ & Sex & $\begin{array}{l}\text { Arbitrary } \\
\text { Units }^{\top}\end{array}$ & Level $0^{\top}$ & Level $\mathbf{1}^{\top}$ & Level $2^{\top}$ & $\begin{array}{l}\text { Level } 3^{\top} \\
\text { (Nucleoids \%) }\end{array}$ & Level $4^{\top}$ \\
\hline Negative & $\mathrm{F}$ & $29.51 \pm 14.10$ & $83.12 \pm 4.35$ & $8.47 \pm 3.18$ & $5.17 \pm 2.90$ & $2.26 \pm 1.43$ & $0.98 \pm 0.44$ \\
\hline \multirow[t]{2}{*}{ CF11 } & $\mathrm{F}$ & $55.26 \pm 8.49^{a}$ & $64.09 \pm 3.74^{a}$ & $23.41 \pm 3.11^{\mathrm{a}}$ & $7.01 \pm 1.88^{a}$ & $4.13 \pm 1.81^{\mathrm{a}}$ & $1.36 \pm 1.09^{a}$ \\
\hline & $M$ & $61.59 \pm 3.29^{a}$ & $60.98 \pm 2.91^{a}$ & $25.37 \pm 2.52^{\mathrm{a}}$ & $6.95 \pm 2.32^{\mathrm{a}}$ & $4.48 \pm 2.57^{a}$ & $2.22 \pm 1.46^{a}$ \\
\hline CF21 & $\mathrm{F}$ & $100.98 \pm 14.38^{\mathrm{abc}}$ & $34.09 \pm 2.94^{\mathrm{abc}}$ & $44.61 \pm 2.14^{\mathrm{abc}}$ & $11.41 \pm 2.71^{a b c}$ & $6.01 \pm 1.72^{\mathrm{abc}}$ & $3.88 \pm 1.99^{\mathrm{abc}}$ \\
\hline BL11 & $\mathrm{M}$ & $56.91 \pm 2.75^{\mathrm{a}}$ & $63.78 \pm 4.41^{a}$ & $23.17 \pm 3.57^{\mathrm{a}}$ & $7.13 \pm 1.22^{a}$ & $4.20 \pm 1.51^{\mathrm{a}}$ & $1.72 \pm 0.46^{a}$ \\
\hline \multirow[t]{2}{*}{ BL21 } & $\mathrm{F}$ & $100.72 \pm 10.68^{\mathrm{abc}}$ & $35.66 \pm 1.46^{\mathrm{abc}}$ & $43.10 \pm 3.61^{\mathrm{abc}}$ & $10.32 \pm 1.99^{\mathrm{abc}}$ & $5.90 \pm 1.22^{\mathrm{abc}}$ & $4.82 \pm 3.39^{\mathrm{abc}}$ \\
\hline & $M$ & $103.13 \pm 17.33^{\mathrm{abc}}$ & $33.92 \pm 2.11^{\mathrm{abc}}$ & $44.56 \pm 5.28^{\mathrm{abc}}$ & $10.32 \pm 3.82^{\mathrm{abc}}$ & $6.87 \pm 2.47^{\mathrm{abc}}$ & $4.33 \pm 2.11^{\mathrm{abc}}$ \\
\hline
\end{tabular}

T. all statistical analysis was carried out using the Mann Whitney $U$ test, $p<0.05$. ( $X$ average; SD Standard Deviation, for the two experimental replics). 1. Administration by i.p route. $a=i$ if differs with the negative control, $b=$ it differs among the different treatments for the same mutagen and $c=$ it differs among mutagens without keeping in mind the treatment. $C F 1=$ Cyclophosphamide administered 24 hours before the euthanasia and CF2=Cyclophosphamide administered 48 and 24 hours before the euthanasia. BL1= Bleomycin administered 24 hours before the euthanasia and BL2= Bleomycin administered 48 and 24 hours before the euthanasia.

Permission of animal ethics committee : During the experimental process the established ethical principles were respected for the research with laboratory animals. The authors declare that this work was made on the base of good practices of preclinical laboratory present in the national regulation of protocols approval of research in the Cuban republic. It is also declared on the part of the authors that it was obtained the consent of protocol approval and report in writing when this research began.

\section{Results}

The two CF treatments in the alkaline comet assay differ significantly in both sexes. Bigger induction on DNA damage and arbitrary units were obtained when administering the CF 48 and $24 \mathrm{hr}$ before the euthanasia (Table 1). The CF administered twice induced until up to 3.88-4.72 nucleoids per cent with fourth degree of damage. The two groups treated with BL also differed significantly. Only with the BL administration in two doses was possible to induce high levels of damage. The values of the fourth level of damage for this group were among 4.33-4.82\%. In the figure a, b, c and d, typical comets of fourth level of damage for each experimental group are observed including the controls group in both sexes (Figure e and $f$ ).

In the micronucleus assay (Table 2), it was other

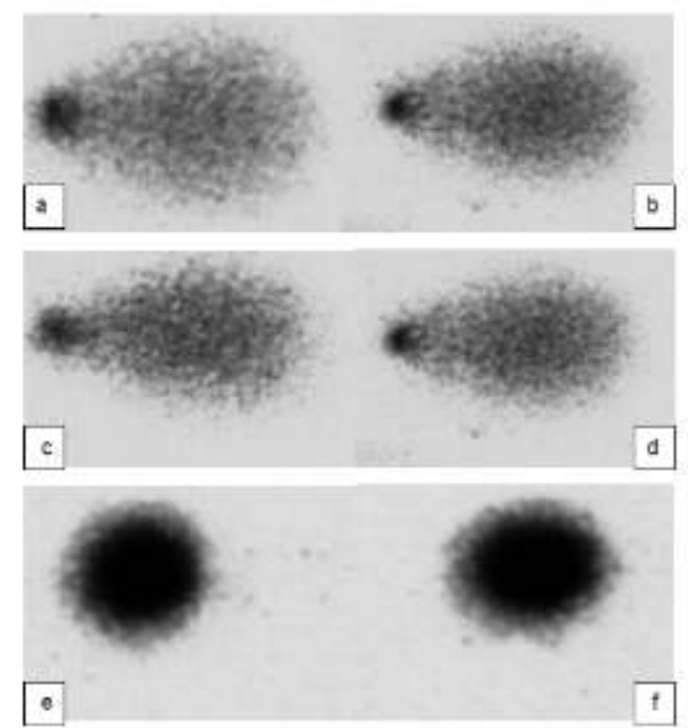

Figure. $\mathbf{a}=$ Comet of peripheral blood leukocytes with 4 level of DNA damage, it was treated with cyclophosphamide administered 24 hours before the euthanasia.

Figure. $\mathbf{b}=$ Comet of peripheral blood leukocytes with 4 level of DNA damage, it was treated with cyclophosphamide administered in two occasions, 48 and 24 hours before the euthanasia.

Figure. $\mathbf{c}=$ Comet of peripheral blood leukocytes with 4 level of DNA damage, it was treated with bleomycin administered 24 hours before the euthanasia.

Figure. $\mathbf{d}=$ Comet of peripheral blood leukocytes with 4 level of DNA damage, it was treated with bleomycin administered in two occasions, 48 and 24 hours before the euthanasia.

Figure. $\mathbf{e}=$ Comet of peripheral blood leukocytes with 0 level of DNA damage, negative control group treated with $\mathrm{NaCl} 0,9 \%$ (female).

Figure. $\mathbf{f}=$ Comet of peripheral blood leukocytes with 0 level of DNA damage, negative control group treated with $\mathrm{NaCl} 0,9 \%$ (male). 
Assessment of Sprague Dawley rats as biomodel in two antigenotoxicity assays

Table-2. Cytotoxicity and genotoxicity indexes in bone marrow cells of Sprague Dawley rats of both sexes tried with cyclophosphamide and bleomycin.

\begin{tabular}{|c|c|c|c|c|c|}
\hline Groups & $n$ & $\mathbf{P E}^{\top}$ & $\mathrm{NE}^{\top}$ & $\mathrm{PE} / \mathrm{NE}^{\mathrm{T}}$ & MN-PE $(\%)^{\top}$ \\
\hline \multicolumn{6}{|l|}{ Males } \\
\hline $\mathrm{CNa}$ & 10 & $1116 \pm 10,21$ & $884 \pm 10,21$ & $1,26 \pm 0,04$ & $0,18 \pm 0,06$ \\
\hline $\mathrm{Cf} 2 \mathrm{a}$ & 10 & $976 \pm 4,32^{\circ}$ & $1024 \pm 4,32^{c}$ & $0,95 \pm 0,05^{\circ}$ & $1,22 \pm 0,35^{\mathrm{c}}$ \\
\hline BL1a & 10 & $981 \pm 6,85^{\mathrm{bc}}$ & $1019 \pm 6,85^{\mathrm{bc}}$ & $0,96 \pm 0,03^{b c}$ & $1,18 \pm 0,47^{\mathrm{bc}}$ \\
\hline $\begin{array}{l}\text { BL2a } \\
\text { Females }\end{array}$ & 10 & $989 \pm 4,66^{\mathrm{bc}}$ & $1011 \pm 4,66^{\mathrm{bc}}$ & $0,98 \pm 0,04^{\mathrm{bc}}$ & $1,14 \pm 0,51^{\mathrm{bc}}$ \\
\hline CF1a & 10 & $924 \pm 9,48^{\mathrm{aAc}}$ & $1076 \pm 9,48^{\mathrm{aAc}}$ & $0,86 \pm 0,04^{\mathrm{aAc}}$ & $1,77 \pm 0,56^{\mathrm{aAc}}$ \\
\hline CF2a & 10 & $963 \pm 3,22^{c}$ & $1037 \pm 9,48^{c}$ & $0,93 \pm 9,48^{c}$ & $1,09 \pm 0,20^{\circ}$ \\
\hline $\mathrm{Bl} 1 \mathrm{a}$ & 10 & $972 \pm 5,31^{\mathrm{bc}}$ & $1028 \pm 9,48^{b c}$ & $0,95 \pm 9,48^{b c}$ & $1,11 \pm 0,28^{b c}$ \\
\hline BL2a & 10 & $983 \pm 4,44 b c$ & $1017 \pm 9,48 b c$ & $0,97 \pm 9,48 b c$ & $1,05 \pm 0,36 b c$ \\
\hline
\end{tabular}

T. All statistical analysis was carried out using the ANOVA test, $p<0.05$. ( $X$ average; SD Standard Deviation, two experimental replics). a. Administration by i.p route. Count in 2000 cells/animal. CF1= Cyclophosphamide administered 48 and 24 hours before the euthanasia and CF2= Cyclophosphamide administered 24 hours before the euthanasia. BL1= Bleomycin administered 48 and 24 hours before the euthanasia and BL2= Bleomycin administered 24 hours before the euthanasia. Different letters ( $a$ and $b$ ) they differ when comparing the results among mutagens per sex. (A) Results that they differ when comparing the different treatments using the same mutagen per sex. (c) They differ when comparing the results against the negative control (CN). PE= Polychromatic Erythrocytes, NE= Normochromatic Erythrocytes, $\mathrm{MN}=\mathrm{Micronucleus.}$

obtained as a result that the $\mathrm{CF}$ administered 48 and 24 hr before the euthanasia it differed significantly with the other groups. The $\mathrm{CF}$ was induced the formation of 250-260 micronucleus in bone marrow cells (both sexes). However the results obtained after the unique administration with $\mathrm{CF}$ and the two types of treatments with BL they didn't show differences in the analysed variables in the micronucleus assay.

\section{Discussion}

It was demonstrated to induce an acceptable genotoxic response in the lymphocytes of peripheral blood when the groups tried with mutagens differ significantly with the solvent control group. The results found in both assays when administering the $\mathrm{NaCl}$ to $0,9 \%$ are similar to those obtained by our work group when evaluating the spontaneous damage in this rat species (10).

The opposing differences with the $\mathrm{CF}$ in two different outlines in both sexes were given to be this mutagen an accumulative genotoxic character, being the variable time is decisive in the increase of their harmful effect on DNA(11).

On the other hand it is justified to have bigger biodisponibility of the mutagen when differing the two groups tried with BL, being related the variable number of detected exhibition-damage (12). Since the BLconstitutes a true and direct mutagen (13).

The results obtained with $\mathrm{CF}$ affirm that it is possible to use this mutagen in the induction of damage in the primary structure on $\operatorname{DNA}(1,9)$. The $\mathrm{CF}$ is a cheap mutagen, easy to manipulate, manifesting smaller risk for the personnel and easy treatment of deactivation of useful polluted during the experiment $(14,15)$, these advantages make that you can implement the CF with more use in this antigenotoxicity assay by means of this technique, when it also evaluates genotoxicity and oxidative stress effects of new drugs. The small head of the comet can be observed in (b) and (d) figure; with the great increment of the migration and bigger quantity of degraded fragments on DNA. This is associated with the DNA fragmentation during the necrosis processes and apoptosis induced by both mutagens (16).

There were opposing statistical differences among the CF administered in two occasions and the administered in unique dose in the genotoxicity and cytotoxicity indexes in the micronucleus assay. The action of the $\mathrm{CF}$ it is potential when being administered in two occasions $(15,17)$.

They were differences between $\mathrm{CF}$ administered in two occasions with the two treatments used in the BL in micronucleus assay; this could be for the difference of genotoxic mechanisms among mutagens or for the dependent susceptibility of the species in the outlines of used treatments were not observed significant differences among the $\mathrm{CF}$ and the $\mathrm{BL}$ administered in two occasions (11). For that the predominant factor can be the mutagenic effects that the $\mathrm{CF}$ induces linked to its mechanism, being detected by this assay with high specificity and fidelity, and in smaller measure the species factor $(7,11)$.

This study allowed concluding that it is more feasible to administer the CF in two occasions, if you 
Assessment of Sprague Dawley rats as biomodel in two antigenotoxicity assays

Table-3. Total micronucleis in bone marrow of Sprague Dawley rats in both sexes tried with cyclophosphamide and bleomycin.

\begin{tabular}{|c|c|c|c|c|c|}
\hline Groups & n & $\mathbf{M N}^{\top}$ & PE (1 MN $)^{\top}$ & PE $(2 \mathrm{MN})^{\top}$ & P E $(2>M N)^{\top}$ \\
\hline $\mathrm{CN}^{\mathrm{a}}$ & 10 & 25 & 19 & 5 & 1 \\
\hline $\mathrm{CF}^{\mathrm{a}}$ & 10 & $174^{c}$ & $120^{c}$ & $47^{c}$ & $7^{c}$ \\
\hline $\mathrm{BL} 1^{\mathrm{a}}$ & 10 & $168^{\mathrm{bc}}$ & $118^{b c}$ & $45^{b c}$ & $5^{\mathrm{bc}}$ \\
\hline$B L 2^{a}$ & 10 & $162^{b c}$ & $115^{\mathrm{bc}}$ & $42^{\mathrm{bc}}$ & $5^{\mathrm{bc}}$ \\
\hline $\mathrm{CF} 1^{\mathrm{a}}$ & 10 & $251^{\mathrm{aAc}}$ & $153^{\mathrm{aAc}}$ & $84^{\mathrm{aAc}}$ & $14^{\mathrm{aAc}}$ \\
\hline $\mathrm{CF}^{\mathrm{a}}$ & 10 & $155^{c}$ & $119^{c}$ & $33^{c}$ & $4^{c}$ \\
\hline $\mathrm{BL} 1^{\mathrm{a}}$ & 10 & $158^{\mathrm{bc}}$ & $122^{\mathrm{bc}}$ & $30^{\mathrm{bc}}$ & $6^{\mathrm{bc}}$ \\
\hline $\mathrm{BL} 2^{\mathrm{a}}$ & 10 & $149^{\mathrm{bc}}$ & $117^{\mathrm{bc}}$ & $27^{c}$ & $5^{\mathrm{bc}}$ \\
\hline
\end{tabular}

T All statistical analysis was carried out using the ?2 non parametric test, $p<0.01$. aAdministration by i.p route. Count in 2000 $\mathrm{PE} /$ animal. $\mathrm{CF} 1=$ Cyclophosphamide administered 48 and 24 hours before the euthanasia and CF2= Cyclophosphamide administered 24 hours before the euthanasia. BL1= Bleomycin administered 48 and 24 hours before the euthanasia and BL2= Bleomycin administered 24 hours before the euthanasia. Different letters ( $a$ and $b)$ they differ when comparing the results among mutagens per sex. (A) Results that they differ when comparing the different treatments using the same mutagen per sex. (c) They differ when comparing the results against the negative control $(\mathrm{CN})$. $\mathrm{MN}=$ Micronucleus, $\mathrm{PE}=\mathrm{Polych}$ romatic erythrocytes.

want to induce the micronucleus formation efficiently in bone marrow of SD rats of both sexes.

These results obtained in both assays have a great utility since they allow using the best design to study the drugs with in vivo antigenotoxicity effects demonstrated by means of these biomodels (18-20).

\section{Conclusions}

Higher induction of the strand breaks (SB) and alkali-labile sites formation on DNA damage were obtained with the use of the cyclophosphamide and bleomycin, both in the design of 48 and $24 \mathrm{hr}$ administration before the euthanasia. In the mironucleis assay was obtained high results of induction the micronucleus formation in bone marrow cells with cyclophosphamide was administered 48 and $24 \mathrm{hr}$ before euthanasia in both sexes. These results are useful in studies of drugs evaluation that they have not been explored in to the in vivo antigenotoxicity environment.

\section{Acknowledgements}

The authors thank to the technical personnel of the animal facilities installation from Research Vicepresidency of the Finlay Institute, Cuba.

\section{References}

1. García, O., Mandina, T. (2005). DNA damage evaluated by the comet assay in lymphocytes of children with $137 \mathrm{Cs}$ internal contamination caused by the Chernobyl accident Mut Res, 565(2):191-197.

2. Collins, A.R. (2004). The Comet Assay for ADN Damage and Repair. Principles. Mol. Biotech, 26:249-261.
3. Hayashi, M.; Tice, R., Macgregor, J.T., Anderson, D. Blakey, D., and Kirsh-Volders, M. (1993). In vivo rodent erythrocyte micronucleus assay. Mutation Research, 5:120 134.

4. Arencibia, D.F.; Vidal, A., Rosario, L.A., and Delgado, L. (2010). Comparison of the Sprague Dawley rat's response against cyclophosphamide and bleomycin in the head sperm morphology assay. ARS Pharmaceutica, 51(3):155-162.

5. Arencibia, D.F.; Vidal, A., Rosario, L.A., Suárez, Y.E., and Delgado, L. (2011). Biomodels for the micronucleis induction on bone marrow cells by cyclophosphamide and bleomycin. VacciMonitor, 20(1):28-33

6. Arencibia, D.F, and Rosario, L.A. (2011). Balb/c mice's response against bleomycin and cyclophosphamide in the head sperm morphology assay. REDVET, XII (2):1-13.

7. Arencibia, D.F.; Rosario, L.A., Morffi, J., and Curveco, D (2009). Strategies in the genotoxic evaluation. Retel, 23(3):23-40.

8. Arencibia, D.F, and Rosario, L.A. (2010). Some considerations about the development of technique for the in vivo comet assay in leukocytes of peripheral blood and liver cells. Retel, 26(1):1-12.

9. Arencibia, D.F; Rosario, L.A., Morffi, J., and Curveco, D. (2009). Development and standardization of the three genotoxicity assays technique. Retel, 25(3):22-38.

10. Arencibia, D.F, and Rosario, L.A. (2010). Evaluation of Sprague Dawley rats as biomodels to detect damage on DNA in leukocytes of peripheral blood and hepatic cells, by means of the comet assay. ARS Pharmaceutica, 51(1):49-56.

11. Arencibia, D.F, and Rosario, L.A. (2010). SD rats response to the cyclophosphamide and bleomycin administration by means of the chromosomal aberration assay in bone marrow. Retel, 28(1):1-14.

12. Cancino, L.; Leiva, A., Garrido, G., Cossío, M., and Prieto, E. (2001). VIMANG: The antigenotoxic effects and modulator of the glutathion peroxidase and glutathion-Stransferase enzymes. Rev Cub Invest Biomed, 20(1):48-53.

13. Rodríguez, I.; Valdés, Y.C., and Proveyer, S. (2004). Cytostatic: risky medications. Rev Cub Med, 43(2-3):15-19.

14. Carmignani, S.S., and Raymund, G.G. (1997). Safe handling 
of cytotoxic drugs in the physician's office: a procedure manual model. Oncol Nurs Forum, 24 (suppl 1):41-48.

15. Prieto, G.; Errecalde, C., and Trotti, N. (1999). Clinical pharmacology of the antineoplastic. Monog Med Vet, 19(2):1-8.

16. Meintieres, S.; Nesslany, F., Pallardy, M., and Marzin, D. (2003). Detection of ghost cells in the standard alkaline comet assay is not a good measure the apoptosis. Envir. Mol. Mut, 41:260-269.

17. Mani, S.; Buzaid, A.C., and Cadman, E.C. (1995). Pharmacology of antineoplastic agents, multidrug resistance, and the feature. En: Hoffman R, et al eds. Hematology: basic principles and practice. 2 ed. Churchill
Livingstone New York, p.915-940

18. Shi, S.T.; Wang, Z.Y., Smith, T.J., Hong, J.Y., Chen, WF., and Yang, C.S. (1994). Effects of green tea and black tea on 4(methylnitrosoamino)-1-(3-pyridil)-1-butanone bioactivation, DNA methylation, and lung tumorigenesis in $\mathrm{A} / \mathrm{J}$ mice. Cancer Res, 54(17):4641-4647.

19. Matuo, R.; Oliveira, R.J., Silva, A.F., Mantovani, M.S. and Ribeiro, L.R. (2007). Anticlastogenic Activity of Aqueous Extract of Agaricus blazei in Drug-Metabolizing Cells (HTCs) During Cell Cycle. Toxic Mechan Meth, 17(3):147-152.

20. Díaz, S.; González, I., González, R. and Coll, F. (2008). In vivo antigenotoxic assessment of a brasinosteroid analogue. Rev Cub Farm, 42 (Especial Supplement 3):75-76. 